\title{
Application of loop-mediated isothermal amplification assay in the detection of herpesvirus of turkey (FC 126 strain) from chicken samples in Nigeria
}

\author{
A. J. Adedeji ${ }^{1}$, P. A. Abdu' ${ }^{2}$, P. D. Luka $^{3}$, A. A. Owoade ${ }^{4}$ and T. M. Joannis ${ }^{5}$
}

1. Viral Research Division, National Veterinary Research Institute, Vom, Nigeria; 2. Department of Veterinary Medicine, Faculty of Veterinary Medicine, Ahmadu Bello University, Zaria, Nigeria; 3. Biotechnology Division, National Veterinary Research Institute, Vom, Nigeria; 4. Department of Veterinary Medicine, Faculty of Veterinary Medicine, University of Ibadan, Nigeria; 5. Regional Laboratory for Animal Influenza and Other Transboundary Animal Diseases, National Veterinary Research Institute, Vom, Nigeria.

Corresponding author: A. J. Adedeji, e-mail: yinkadeji@yahoo.com

Co-authors: PAA: paabdu2004@yahoo.com,PDL: pamluka08@gmail.com,AAO: aowoade43@gmail.com, TMJ: tmjoannis@yahoo.com

Received: 31-05-2017, Accepted: 24-10-2017, Published online: 26-11-2017

doi: 10.14202/vetworld.2017.1383-1388 How to cite this article: Adedeji AJ, Abdu PA, Luka PD, Owoade AA, Joannis TM (2017) Application of loop-mediated isothermal amplification assay in the detection of herpesvirus of turkey (FC 126 strain) from chicken samples in Nigeria, Veterinary World, 10(11): 1383-1388.

\begin{abstract}
Aim: This study was designed to optimize and apply the use of loop-mediated isothermal amplification (LAMP) as an alternative to conventional polymerase chain reaction (PCR) for the detection of herpesvirus of turkeys (HVT) (FC 126 strain) in vaccinated and non-vaccinated poultry in Nigeria.

Materials and Methods: HVT positive control (vaccine) was used for optimization of LAMP using six primers that target the HVT070 gene sequence of the virus. These primers can differentiate HVT, a Marek's disease virus (MDV) serotype 3 from MDV serotypes 1 and 2. Samples were collected from clinical cases of Marek's disease (MD) in chickens, processed and subjected to LAMP and PCR.

Results: LAMP assay for HVT was optimized. HVT was detected in $60 \%(3 / 5)$ and $100 \%(5 / 5)$ of the samples analyzed by PCR and LAMP, respectively. HVT was detected in the feathers, liver, skin, and spleen with average DNA purity of 3.05-4.52 $\mu \mathrm{g}$ DNA/mg (A260/A280) using LAMP. Conventional PCR detected HVT in two vaccinated and one unvaccinated chicken samples, while LAMP detected HVT in two vaccinated and three unvaccinated corresponding chicken samples. However, LAMP was a faster and simpler technique to carry out than PCR.

Conclusion: LAMP assay for the detection of HVT was optimized. LAMP and PCR detected HVT in clinical samples collected. LAMP assay can be a very good alternative to PCR for detection of HVT and other viruses. This is the first report of the use of LAMP for the detection of viruses of veterinary importance in Nigeria. LAMP should be optimized as a diagnostic and research tool for investigation of poultry diseases such as MD in Nigeria.
\end{abstract}

Keywords: herpesvirus of turkeys, loop-mediated isothermal amplification procedure, Nigeria.

\section{Introduction}

Marek's disease (MD) initially described by József Marek in 1907 is a highly contagious lymphoproliferative viral disease of poultry caused by MD virus (MDV) [1,2]. The MDV is a double-stranded linear DNA virus belonging to the family Herpesviridae, subfamily Alphaherpesvirinae, genus Mardivirus (GaHV-2) [3]. MDV is classified into three serotypes, Gallidherpesvirus-2 or serotype 1 (MDV-1), Gallid herpesvirus 3 or serotype 2 (MDV-2), and Meleagrid herpesvirus 1 (MDV-3, serotype 3), or herpesvirus of turkeys (HVT) [3]. Clinical MD is caused by MDV-1 strain, while MDV-2 and HVT are nonpathogenic and

Copyright: Adedeji, et al. Open Access. This article is distributed under the terms of the Creative Commons Attribution 4.0 International License (http://creativecommons.org/licenses/ by/4.0/), which permits unrestricted use, distribution, and reproduction in any medium, provided you give appropriate credit to the original author(s) and the source, provide a link to the Creative Commons license, and indicate if changes were made. The Creative Commons Public Domain Dedication waiver (http:// creativecommons.org/publicdomain/zero/1.0/) applies to the data made available in this article, unless otherwise stated. used as vaccine strains [2,4]. MD affects chickens, quails, turkeys, pheasants, and game fowl [3]. MDV is highly ubiquitous and contagious with long-term infectivity of poultry house environment and eradication of MD is very difficult [5]. Prevention of MD is, therefore, mainly based on vaccination, improved biosecurity, and selection for genetic resistance [5].

The development of MD vaccines was a major breakthrough in basic cancer research; moreover, it is the first neoplastic disease controlled by vaccination $[6,7]$. Despite the successes recorded with its usage, increase in virulence of MDV has accompanied the use of MD vaccines [7,8]. In addition, vaccination against MDV does not lead to a sterilizing immunity and vaccinated birds become protected from clinical disease but continue to shed and transmitted the virus $[5,7]$.

Several advances in laboratory detection of MDV have been reported, particularly using molecular techniques such as polymerase chain reaction (PCR) and Real Time-PCR which can detect and quantify field and vaccine strains of 
MDV like HVT $[9,10]$. However, the requirement of using costly equipment for routine testing by small laboratories and field veterinarians remains a challenge [11]. Despite the availability of different detection techniques, there is still need for a rapid and simple molecular method that does not require expensive laboratory equipment. Alternative methods to standard PCR include nucleic acid sequencebased amplification (NASBA) and loop-mediated isothermal amplification (LAMP). LAMP is based on amplification of specific genetic loci [12]. LAMP also uses isothermal condition provided by a water bath or heating bloc and Bst or Bsm polymerases, which have DNA strand displacement activity, along with four to six primers [13]. LAMP technique can amplify a few copies of DNA to $10^{9}$ in $<1 \mathrm{~h}$ under isothermal conditions [13].

The first report of MD in Nigeria was in 1962, subsequently several outbreaks have been reported in Nawathe et al. [14], Fatunmbi and Adene [15], Owoade and Oni [16], Wakawa et al. [17], Jwander et al. [18]. In a 2013 report, Nigeria was one of the countries with increasing prevalence of MD in the past 10 years, despite being one of the countries that routinely vaccinates chickens against MD [19]. In spite of routine vaccination, poultry farmers in Jos, Plateau State have been reporting outbreaks suspected to be MD.

This study was designed to optimize and apply the use of LAMP as an alternative to PCR for the detection of HVT in vaccinated and unvaccinated poultry in Nigeria.

\section{Materials and Methods}

\section{Ethical approval}

Ethical approval was not considered, because clinical samples were collected from dead chickens submitted for routine diagnosis at the Veterinary Clinic.

\section{Sample collection}

Samples were collected from clinical cases of MD presented to a Veterinary Clinic in Jos, Plateau State, Nigeria. The samples were collected in 2014 and transported on ice and stored at $-70^{\circ} \mathrm{C}$ in the Viral Research Division of the National Veterinary Research Institute, Vom, Plateau State, Nigeria. The vaccination history and postmortem findings of each case were recorded.

\section{DNA extraction}

One gram of tissue from each sample was weighed and homogenized using pestle and mortar with sterile glass. Thereafter, $9 \mathrm{ml}$ of phosphate-buffered saline was added and centrifuged in a refrigerated centrifuge at 10,000 rpm for 5 min to make $10 \%$ tissue suspension. The supernatant was decanted into a sterile tube and kept at $4^{\circ} \mathrm{C}$ for DNA extraction and the pellet discarded into a disinfectant. The viral DNA extraction was carried out using QIAamp DNA Mini kit from Qiagen (Qiagen, Hilden, Germany) following the manufacturer's instructions. DNA extracts were evaluated by spectrophotometry (BioPhotometer; Eppendorf Scientific, Hamburg, Germany) at A260/ A280 and checking on 1.5\% agarose gel electrophoresis and kept at $+4^{\circ} \mathrm{C}$ before use.

\section{Primers for PCR and LAMP}

The published PCR and LAMP primer sequences used for this study are listed in Table-1 [20]. The primers were designed based on the HVT070 gene sequence of HVT (FC-126 Strain) with accession number NC 002641.1 which can differentiate MDV-3 or HVT from MDV-1 and MDV-2. The outer primers, MDV-3, F3 and MDV-3 B3, were used for the PCR and all for LAMP. The LAMP primers consist of three set of primers, the outer primers MDV-3 F3 and B3, inners primers (MDV-3 FIP and BIP), and additionally loop primers (MDV-3 LF and MDV-3 LB) designed to accelerate the LAMP reaction [20].

\section{Optimization of LAMP}

LAMP assay was optimized using different concentrations of all the primers and reagents in the kit (OmniAmp ${ }^{\mathrm{TM}}$ RNA and DNALAMP Kit, Lucigen USA). These were conducted as follows: Betaine $(0.2,0.3,0.4,0.5 \mathrm{M})$, OmniAmp DNA Polymerase $50 \times(0.5,1 \mu \mathrm{l}), \mathrm{MgSO}_{4}(0,4,8,12 \mathrm{mM}), 10 \mathrm{mM}$ dNTPs $(0.8,1.6,2,4 \mu 1)$, DNA template $(1.5,2,2.5 \mu 1$ of average 3.05-4.52 $\mu \mathrm{g} \mathrm{DNA} / \mathrm{mg}$ ), outer primers F3 and $\mathrm{B} 3(7.5,10 \mathrm{pmol})$, inner primers FIP and BIP (40, $60 \mathrm{pmol})$, loop primers LF and BF $(15,20 \mathrm{pmol})$, different temperature reaction conditions $(60,65,68$, $\left.70^{\circ} \mathrm{C}\right)$, and time $(25,30,35 \mathrm{~min})$ as well as termination temperature $\left(80,95^{\circ} \mathrm{C}\right)$ and time $(2,5 \mathrm{~min})$.

Table-1: The list of primer sequences of HVT (FC-126) used for polymerase chain reaction and loop-mediated isothermal amplification procedure.

\begin{tabular}{|c|c|c|c|}
\hline Primer ID & Sequence $\left(5^{\prime}-3^{\prime}\right)$ & $\begin{array}{l}\text { Marek's disease } \\
\text { virus serotype }\end{array}$ & Reference \\
\hline MDV-3F3 & ATAAATTATATCGCTAGGACAGAC & $\begin{array}{l}\text { HVT (FC } 126 \\
\text { strain) }\end{array}$ & Woźniakowski et al. [20] \\
\hline MDV-3B3 & ACGATGTGCTGTCGTCTA & & \\
\hline MDV-3FIP & CCAGGGTATGCATATTCCATAACAGTITCCAAACGACCTTTATCCCA & & \\
\hline MDV-3BIP & CCAGAAATTGCACGCACGAGTTTTAGAATTTGTGCATTTAGCCTT & & \\
\hline MDV-3LF & TTGAGAAGAGGATCTGACTG & & \\
\hline MDV-3LB & GCGTCATTGGTTTTACATTT & & \\
\hline
\end{tabular}

$\mathrm{HVT}=$ Herpesvirus of turkeys, MDV=Marek's disease virus 
LAMP

The LAMP mix (OmniAmp ${ }^{\mathrm{TM}}$ RNA and DNA LAMP Kit, Lucigen, Middleton WI, USA) was done at two different times in $25 \mu \mathrm{l}$ volume mix consisting of 10X DNA polymerase buffer C $2.5 \mu 1$, OmniAmp DNA polymerase $50 \times 1 \mu \mathrm{l}$, the primers were MDV F3 and B3 10 pmol each, MDV LF and LB 20 pmol each, MDV FIP and BIP 40 pmol each, $100 \mathrm{mM} \mathrm{MgSO} 4 \mathrm{mM}$, dNTPs $4 \mu \mathrm{l}$, Betaine 0.4M, and nuclease-free water and DNA template $2 \mu 1$. The LAMP amplification reactions were performed at $70^{\circ} \mathrm{C}$ for $30 \mathrm{~min}$ and subsequently enzyme activity was stopped by holding the mix on ice at $4^{\circ} \mathrm{C}$ while a second stage incubation was done at $95^{\circ} \mathrm{C}$ for $5 \mathrm{~min}$. The amplified products were analyzed on a $1.5 \%$ agarose gel and visualized by staining with ethidium bromide. LAMP-positive samples showed specific ladder-like products ranging from 197 to $1300 \mathrm{bp}$. Bands below the 197-bp product were considered to be primer-dimers.

\section{PCR}

PCR was carried out in $25 \mu 1$ volume reaction mix consisting of Thermo Scientific Dream Taq Green PCR Master Mix (2×) $12.5 \mu 1,20$ pmol of MDV F3 and B3 primers, nuclease-free water and DNA, $2 \mu 1$. The thermal cycling profile included initial denaturation $94^{\circ} \mathrm{C}$ for $3 \mathrm{~min}$ followed by 35 cycles at $94^{\circ} \mathrm{C}$ for $30 \mathrm{~s}, 55^{\circ} \mathrm{C}$ for $30 \mathrm{~s}$, and $72^{\circ} \mathrm{C}$ for $1 \mathrm{~min}$ for denaturation, annealing, and extension, respectively, and final extension at $72^{\circ} \mathrm{C}$ for $7 \mathrm{~min}$. HVT (FC-126) vaccine (ABIC, Israel) was used as positive control and aliquot of molecular grade water was used as the negative control and were both subjected to DNA extraction and PCR. The expected band size of positive samples is 200 bps. GelPilot DNA molecular Weight Marker (QIAGEN) 100 bps was used to run the samples.

\section{Results}

\section{Optimized LAMP}

Based on the different variables adjusted, LAMP mix was carried out as described in the materials and methods. The incubation protocol and the LAMP mix with the bright and distinct band patterns of different sizes were subsequently used to run LAMP on clinical samples collected from the field (Figures-1 and 2). The LAMP mix with the bright and distinct band patterns of different sizes were $10 \times$ DNA Polymerase Buffer C $2.5 \mu 1$, OmniAmp DNA Polymerase $50 \times 1 \mu \mathrm{l}$, the outer primers were $10 \mathrm{pmol}$ each, loop primers 20 pmol each, inner primers 40 pmol each, $100 \mathrm{mM} \mathrm{MgSO} 4 \mathrm{mM}$, dNTPs $4 \mu \mathrm{l}$, Betaine 0.4M, and DNA $2 \mu 1$ (Figure-3). The optimized LAMP incubation protocol was initial incubation temperature of $70^{\circ} \mathrm{C}$ for $30 \mathrm{~min}$ and termination temperature of $95^{\circ} \mathrm{C}$ for $5 \mathrm{~min}$. HVT (FC-126) vaccine (ABIC, Israel) was used as positive control, and nuclease-free water was used as the negative control and were both subjected to DNA extraction and LAMP.

\section{Detection of HVT in clinical samples of chickens by PCR and LAMP}

Samples collected were from broilers (2), layers (2) and indigenous free-range chicken (1), the samples were spleen (1), liver (1), and feathers (2), and skin (1) (Table-2 and Figure-3) [20]. The postmortem findings included splenomegaly, hepatomegaly, and skin tumors as listed in Table-2. The layers were vaccinated using HVT by the farmers, while the broilers and the local chicken had no vaccination history. Of the samples collected 60\% (3/5) and 100\% (5/5) were positive for HVT by PCR (Figure-4) and LAMP (Figure-3), respectively. Moreover, HVT was detected in the spleen, feathers, and liver. PCR detected HVT in two of the flocks that were vaccinated and the indigenous local chicken, while HVT was detected in both vaccinated and unvaccinated flocks by LAMP (Table-2). On repetition of the procedure on a different day and on the same set of samples yielded similar results.

\section{Discussion}

LAMP has been used for the detection of viruses of veterinary importance in several countries as a rapid diagnostic tool [21-26]. The use of LAMP as a tool for the detection of viruses affecting livestock has not

Table-2: Postmortem findings and results detection of HVT in clinical samples from poultry by PCR and LAMP in Jos, Plateau State, Nigeria.

\begin{tabular}{|c|c|c|c|c|c|c|}
\hline Type of chicken & Postmortem findings & $\begin{array}{l}\text { Age in } \\
\text { weeks }\end{array}$ & Vaccination history & $\begin{array}{l}\text { Type of } \\
\text { sample }\end{array}$ & $\begin{array}{l}\text { PCR } \\
\text { results }\end{array}$ & $\begin{array}{l}\text { LAMP } \\
\text { results }\end{array}$ \\
\hline Broiler & Splenomegaly & 9 & $\begin{array}{l}\text { Not vaccinated against MD with } \\
\text { HVT }\end{array}$ & Spleen & - & + \\
\hline Broiler & $\begin{array}{l}\text { Splenomegaly, hepatomegaly, } \\
\text { skin tumors }\end{array}$ & 10 & $\begin{array}{l}\text { Not vaccinated against MD with } \\
\text { HVT }\end{array}$ & Liver & - & + \\
\hline Layer & $\begin{array}{l}\text { Hepatomegaly splenomegaly } \\
\text { and enlarged kidneys and } \\
\text { emaciation }\end{array}$ & 60 & $\begin{array}{l}\text { Vaccinated twice with HVT } \\
\text { before day } 21 \text { of age }\end{array}$ & Feather & + & + \\
\hline Layer & Hepatomegaly, splenomegaly & 40 & Vaccinated with HVT & Feather & + & + \\
\hline $\begin{array}{l}\text { Local indigenous } \\
\text { chicken }\end{array}$ & $\begin{array}{l}\text { Hepatomegaly splenomegaly } \\
\text { and skin tumors }\end{array}$ & Unknown & Unknown & Skin & + & + \\
\hline Total & & & & & $3 / 5$ & $5 / 5$ \\
\hline
\end{tabular}

$\mathrm{HVT}=$ Herpesvirus of turkeys, MD=Marek's disease, $\mathrm{PCR}=$ Polymerase chain reaction, LAMP=Loop-mediated isothermal amplification 


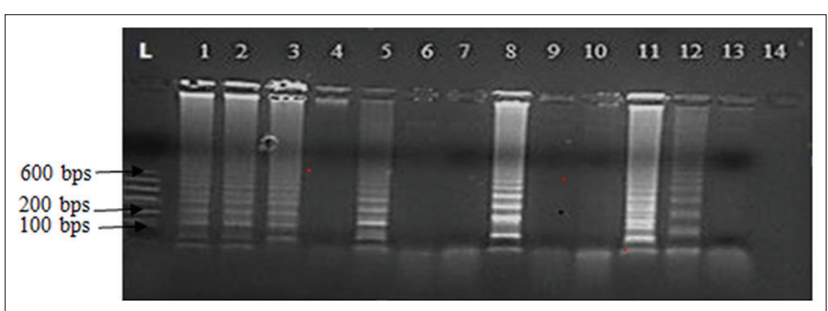

Figure-1: Agarose gel of loop-mediated isothermal amplification (LAMP) with product of herpesvirus of turkeys DNA positive control using the LAMP primers. Lanes 1-14 were the results using different concentration of reagents. Lanes 1-3 (positive control in the kit), Lane 4 (10x buffer C $2.5 \mu \mathrm{l}$, OmniAmp DNA Polymerase $50 \times 0.5 \mu \mathrm{l}, 100 \mathrm{mM}$ $\mathrm{MgSO}_{4} 0 \mathrm{mM}$, dNTPs $0.8 \mu \mathrm{l}$, Betaine $0.2 \mathrm{M}$, and DNA template $1.5 \mu \mathrm{l})$ Lane $5(10 \times$ buffer C $2.5 \mu \mathrm{l}$, OmniAmp DNA Polymerase $50 \times 1 \mu \mathrm{l}, 100 \mathrm{mM}$ MgSO $44 \mathrm{mM}$, dNTPs $1.6 \mu \mathrm{l}$, Betaine $0.3 \mathrm{M}$, and DNA template $1.5 \mu \mathrm{l}$ ) Lanes 6-7 (10x buffer C $2.5 \mu \mathrm{l}$, OmniAmp DNA Polymerase $50 \times$ $0.5 \mu \mathrm{l}, 100 \mathrm{mM}$ MgSO $1.6 \mathrm{mM}$, dNTPs $2 \mu \mathrm{l}$, Betaine $0.3 \mathrm{M}$, and DNA template $1.5 \mu \mathrm{l})$, Lane 8 (10× Buffer C $2.5 \mu \mathrm{l}$, OmniAmp DNA Polymerase $50 \times 1 \mu \mathrm{l}, 100 \mathrm{mM}$ MgSO $4 \mathrm{mM}$, dNTPs $4 \mu \mathrm{l}$, Betaine $0.4 \mathrm{M}$, and DNA $2 \mu \mathrm{l}$ ). Lanes 9-10 (10× buffer C $2.5 \mu \mathrm{l}$, OmniAmp DNA Polymerase $50 \times 1 \mu \mathrm{l}$ $100 \mathrm{mM} \mathrm{MgSO}{ }_{4} 8 \mathrm{mM}$, dNTPs $1.6 \mu \mathrm{l}$, Betaine $0.4 \mathrm{M}$, and DNA $2.5 \mu \mathrm{l}$ ). Lanes 11 ( $10 \times$ buffer C $2.5 \mu \mathrm{l}$, OmniAmp DNA Polymerase $50 \times 1 \mu \mathrm{l}, 100 \mathrm{mM} \mathrm{MgSO}_{4}, 4 \mathrm{mM}$ dNTPs $4 \mu \mathrm{l}$, Betaine $0.4 \mathrm{M}$, and DNA $2.5 \mu \mathrm{l})$. Lane $12(10 \times$ buffer $\mathrm{C}$ $2.5 \mu \mathrm{l}$, OmniAmp DNA Polymerase $50 \times 1 \mu \mathrm{l}, 100 \mathrm{mM}$ MgSO 4 $4 \mathrm{mM}$, dNTPs $4 \mu \mathrm{l}$, Betaine $0.4 \mathrm{M}$, and DNA $1 \mu \mathrm{l}$ ). Lane 13 (10x buffer C $2.5 \mu \mathrm{l}$, OmniAmp DNA Polymerase $50 \times 1 \mu \mathrm{l}$, $100 \mathrm{mM}$ MgSO4, $8 \mathrm{mM}$ dNTPs $1.6 \mu \mathrm{l}$, Betaine $0.4 \mathrm{M}$, and DNA $2 \mu \mathrm{l}$ ). Lane 14 ( $10 \times$ buffer C $2.5 \mu \mathrm{l}$, OmniAmp DNA Polymerase $50 \times 1 \mu \mathrm{l}, 100 \mathrm{mM}$ MgSO4, $12 \mathrm{mM}$ dNTPs $2 \mu \mathrm{l}$, Betaine $0.4 \mathrm{M}$, and DNA $1.5 \mu \mathrm{l}$ ).

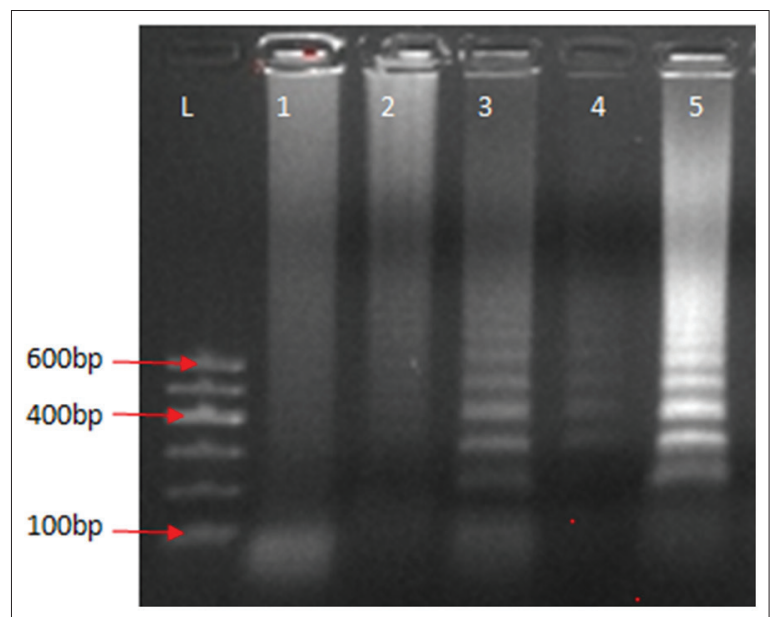

Figure-2: Agarose gel of loop-mediated isothermal amplification procedure DNA product of herpesvirus of turkeys at different temperature conditions; Lane $1\left(60^{\circ} \mathrm{C}\right)$, Lane $2\left(65^{\circ} \mathrm{C}\right)$, Lane $3-4\left(68^{\circ} \mathrm{C}\right)$, Lane $5\left(70^{\circ} \mathrm{C}\right)$. L is $100 \mathrm{bps}$ DNA marker (GelPilot, QIAGEN).

been reported in Nigeria. The results obtained in this study revealed the optimization of LAMP protocol for HVT (FC-126 strain) and HVT detected in 100\% of the clinical samples collected compared to $60 \%$ detection by PCR in the same samples. In addition, LAMP technique was simpler and results turnover time was faster compared to PCR. Although our aim was not to compare the two protocols our findings are

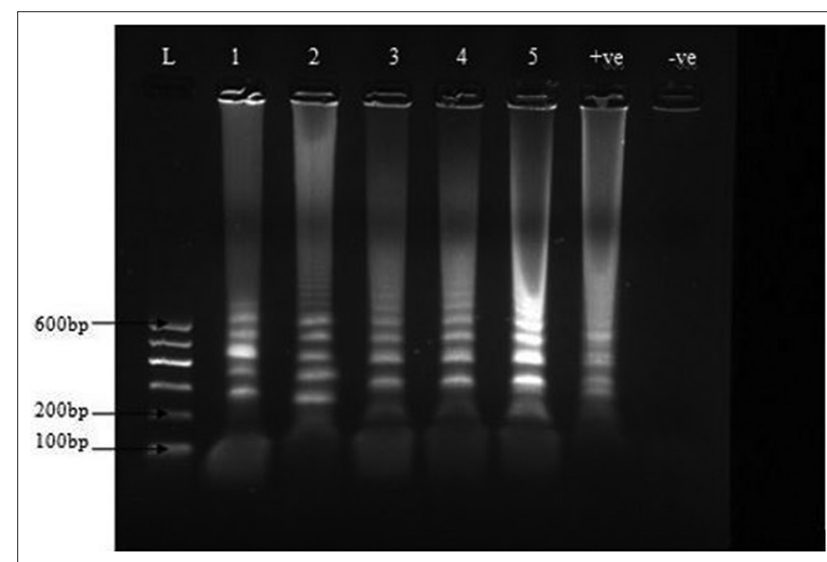

Figure-3: Loop-mediated isothermal amplification (LAMP) procedure DNA product using herpesvirus of turkeys LAMP specific primers, -ve was the negative control, +ve was the positive control, 2-5 were positive. 1 was spleen of broiler, 2 was liver sample of broiler, 3 and 4 feather of layer 5 was DNA skin of indigenous local chicken. $L$ is 100 bps DNA marker (GelPilot, QIAGEN).

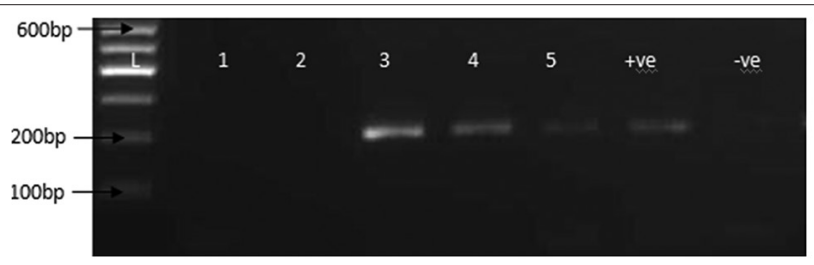

Figure-4: Agarose gel of polymerase chain reaction amplification product of herpesvirus of turkeys FC 126 using specific primers, the positive band was at 200 bps +ve was the positive control, -ve control. L is 100 bps DNA marker (GelPilot, QIAGEN), lanes 1-2 were negative samples and lanes 3-5 were positive samples.

in agreement with several studies in which LAMP was reported to be more sensitive than PCR [11,25,27]. A major challenge for field veterinarians in Nigeria is lack of laboratory support in the investigation of MD and other livestock diseases. Development and adoption of LAMP for pen-site rapid diagnosis of MD and other poultry diseases will strengthen the confidence of veterinarians on the quality of veterinary service delivery and control of the spread of livestock diseases. The use of LAMP can also enhance research on poultry diseases in Nigeria. Vaccination against MD is routinely done in Nigeria using HVT (FC-126 strain) and LAMP can also be used for field detection and monitoring to ensure effective vaccination against MD [20,28]. Moreover, in recent years, HVT is being widely used as a vector of other poultry viruses for the production of vaccines [29-32]. Hence, LAMP may be used for field monitoring of these vaccines. A very important finding in this study is the detection of HVT in unvaccinated broilers and indigenous local chickens diagnosed to be having MD based on clinical and gross pathological findings. Although the vaccination status of the indigenous local chicken is unknown, most indigenous local chickens in Nigeria are usually not vaccinated and kept on free range by rural farmers. HVT like most MDV serotypes is transmitted 
horizontally and hence the broilers and indigenous chicken may have been infected from highly contaminated environment. Studies have revealed that MDV vaccines strains are shed into the environment alongside the pathogenic MDV and transmitted effectively between chickens $[4,33]$. This could be the scenario in this study in which HVT was detected in unvaccinated broilers and local chicken. Although MDV-2 and HVT are not pathogenic, these viruses infect poultry just like all MDV with livelong infectivity which implies that they are continuously shed into the environment through feather follicles [34].

\section{Conclusion and Recommendations}

LAMP assay for the detection of HVT was optimized and used to detect HVT in clinical samples collected from chickens. LAMP assay can be a very good alternative to PCR for the detection of HVT and other viruses. This is the first report of the use LAMP in detection of a virus of veterinary importance in Nigeria. Based on this study, it is recommended that LAMP be optimized as a diagnostic and research tool for viral diseases of poultry such as MD in Nigeria.

\section{Authors' Contributions}

AJA, PAA, and OAA designed the work, AJA collected the samples, AJA and LPD carried out the laboratory analysis. AJA, PAA, TMJ, and LPD wrote the manuscript, TJM and AJA provided the reagents and materials. All authors read and approved the final manuscript.

\section{Acknowledgments}

The authors are thankful to the National Veterinary Research Institute, that partly funded and supported the study.

\section{Competing Interests} interests.

The authors declare that they have no competing

\section{References}

1. Pastoret, P. (2004) Marek's Disease an Evolving Problem. Elsevier Ltd, London. p1-7.

2. Biggs, P.M. and Nair, V. (2012) The long view: 40 years of Marek's disease research and avian pathology. Avian Pathol., 41(1): 3-9.

3. Schat, K.A. and Nair, V. (2008) Marek's disease. In: Saif, Y.M., editor. Disease of Poultry. $12^{\text {th }}$ ed. Blackwell Publishing, Iowa. p452-514.

4. Islam, T., Walkden-Brown, S.W., Renz, K.G., FakhrulIslam, A.F.M. and Ralapanawe, S. (2013) Vaccinationchallenge interval markedly influences protection provided by Rispens CVI988 vaccine against very virulent Marek's disease virus challenge. Avian Pathol., 6: 1-11.

5. Morrow, C. and Fehler F. (2004) Marek's disease: A worldwide problem. Marek's Disease an Evolving Problem. Elsevier Ltd., London. p49-61.

6. Gimeno, I.M. (2004) Future strategies for controlling Marek's disease. In: Marek's Disease an Evolving Problem. Elsevier Ltd., London. p186-199.

7. Gimeno, I.M. (2008) Marek's disease vaccines: A solution for today but a worry for tomorrow? Vaccine, 26: C31-C41.

8. Atkins, K.E., Read, A.F., Savill, N.J., Renz, K.G.,
Islam,A.F.M., Walkden-Brown, S.W. and Woolhouse, M.E.J. (2013) Vaccination and reduced cohort duration can drive virulence evolution: Mareks disease virus and industrialized agriculture. Evolution, 67: 851-860.

9. Zelnik, V. (2004) Diagnosis of Marek's disease In: Marek's Disease an Evolving Problem. Elsevier Ltd, London. p156-167.

10. Cortes, A.L., Montiel, E.R., Lemiere, S. and Gimeno, I.M. (2011) Comparison of blood and feather pulp samples for the diagnosis of Marek's disease and for monitoring Marek's disease vaccination by real time-PCR. Avian Dis., 55: 302-310.

11. Woźniakowski, G., Samorek-Salamonowicz, E. and Kozdrun, W. (2011) Rapid detection of Marek's disease virus in feather follicles by loop-mediated isothermal amplification. Avian Dis., 55: 462-467.

12. Pestana, E.A., Belak, S., Diallo, A., Crowther, J.R. and Viljoen, G.J. (2010) Early, Rapid and Sensitive Veterinary Molecular Diagnostics Real Time PCR Applications. International Atomic Energy Agency and Springer, Dordrecht, Netherlands. p1-319.

13. Notomi, T., Okayama, H., Yonekawa, T., Watana, K., Amino, N. and Hase, T. (2000). Loop-mediated isothermal amplification of DNA. Nucleic Acids Res., 28: 63-68.

14. Nawathe, D.R., Ojeh, C.K. and Onunkwo, O. (1978) Incidence of Marek's disease in Northern states of Nigeria. Vet. Rec., 102: 128.

15. Fatunmbi, O.O. and Adene, D.F. (1986) A ten year prevalence study of Marek's disease and avian leukoses at Ibadan, Nigeria. Acta Vet., 55: 49-53.

16. Owoade, A.A. and Oni, O.O. (2008) Molecular detection of Marek's disease virus in some poultry flocks in southwestern Nigeria by polymerase chain reaction. Niger. Poult. Sci. J., 5(3): 113-118.

17. Wakawa, A.M., Muhammad, Z.K., Aliyu, H.B. and Mohammed, B. (2012) A retrospective analysis of Marek's disease diagnosed at poultry clinic of Ahmadu Bello university, Zaria, Nigeria. J. Vet. Adv., 2(8): 424-429.

18. Jwander, L.D., Abdu, P.A., Ibrahim, N.D.G. and Nok, A.J. (2014) Retrospective studies of Marek's disease diagnosed in four States across Nigeria. J. Vet. Adv., 4(6): 556-563.

19. Dunn, J.R. and Gimeno, I.M. (2013) Current status of Marek's disease in the United States and worldwide based on a questionnaire survey. Avian Dis., 57: 483-490.

20. Woz'niakowski, G., Samorek-Salamonowicz, E. and Kozdrun, W. (2013) Comparison of loop-mediated isothermal amplification and PCR for the detection and differentiation of Marek's disease virus serotype 1,2 and 3. Avian Dis., 57: $1-5$.

21. Xu, J., Zhang, Z., Yin, Y., Cui, S., Xu, S., Guo, Y., Li, J., Wang, J., Liu, X. and Han, L. (2009) Development of reverse-transcription loop-mediated isothermal amplification for the detection of infectious bursal disease virus. J. Virol. Methods, 162: 267-271.

22. Deng, X., Qi, X., Yulong, G.Y., Wang, Y., Qin, L., Gao, H., Gao, L. and Wang, X. (2010) Development of a loop-mediated isothermal amplification method for rapid detection of reticuloendotheliosisvirus. J. Virol. Methods, 168: 82-86.

23. Li, L., Bao, J., Wu, X., Wang, Z., Wang, J., Gong, M., Liu, C. and Li, J. (2010) Rapid detection of peste des petits ruminants virus by a reverse transcription loop-mediated isothermal amplification assay. J. Virol. Methods, 170: 37-41.

24. Wang, Y., Kang, Z., Gao, Y., Qin, L., Chen, L., Wang, Q., Li, J., Gao, H., Qi, X., Lin, H. and Wang, X. (2011) Development of loop-mediated isothermal amplification for rapid detection of avian Leukosis virus subgroup A. J. Virol. Methods, 173: $31-36$

25. Angamuthu, R., Baskaran, S., Gopal, D.R., Devarajan, J. and Kathaperumal, K. (2012) Rapid detection of the Marek's disease viral genome in chicken feathers by loop-mediated isothermal amplification. J. Clin. Microbiol., 50(3): 961-965. 
26. Yamazaki, W., Mioulet, V., Murray, L., Madi, M., Haga, T., Misawa, N., Horii, Y. and King, P.D. (2013) Development and evaluation of multiplex RT-LAMP assays for rapid and sensitive detection of foot-and-mouth disease virus. J. Virol. Methods, 192: 18-24.

27. Wei, X., Xingming, S., Yan, Z., Jing, Z., Mei, W., Changjun, L., Hongyu, C., Shunlei, H., Yanming, Q., Hongyan, C. and Yunfeng, W. (2012) Development of a rapid and specific loop-mediated isothermal amplification detection method that targets Marek's disease virus meqgene. J. Virol. Methods, 183(2): 196-200.

28. Wozniakowski, G. and Niczyporuk, J.S. (2015) Detection of specific UL49 sequences of Marek's diseasevirus CVI988/ rispens strain using loop-mediated isothermal amplification. J. Virol. Methods, 221: 22-28.

29. Afonso, C.L., Tulman, E.R., Lu, Z., Zsak, L., Rock, D.L. and Kutish, G.F. (2001) The genome of turkey herpesvirus. J. Virol., 1: 971-978.

30. Le Gros, F.X., Dancer, A., Giacomini, C., Pizzoni, L., Bublot, M., Graziani, M. and Prandini, F. (2009) Field efficacy trial of a novel HVT-IBD vector vaccine for 1-dayold broilers. Vaccine, 27: 592-596.

31. Rauw, F., Gardin Y., Palya, V., Anbari, S., Lemaire, S., Boschmans M., van den Berg, T., and Lambrecht, B. (2010) Improved vaccination against Newcastle disease by an in ovo recombinant HVT-ND combined with an adjuvanted live vaccine at day-old. Vaccine, 28: 823-833.

32. Prandini, F., Simon, B., Jung, A., Pöppel, M., Lemiere, S. and Rautenschlein, S. (2016) Comparison of infectious bursal disease live vaccines and a HVT-IBD vector vaccine and their effects on the immune system of commercial layer pullets. Avian Pathol., 45(1): 114-125.

33. Walkden-Brown, S.W., Islam, A., Groves, P.J., Rubite, A., Sharpe, S.M. and Burgess, S.K. (2013) Development, application, and results of routine monitoring of Marek's disease virus in broiler house dust using real-time quantitative PCR. Avian Dis., 57: 544-554.

34. Couteaudier, M. and Denesvre, C. (2014) Marek's disease virus and skin interactions. Vet. Res., 45: 36.

$* * * * * * * *$ 